\title{
ECOLOGICAL AND ECONOMIC ASSESSMENT OF THE STATE OF URBAN AREAS AS A MEANS OF A SUSTAINABLE ENVIRONMENTAL SYSTEM
}

\author{
Lomova LA ${ }^{1}$, Sukhina $\mathrm{NYu}^{2}$, Petrovskaya $\mathrm{AV}^{3}$, Karim Al Khadzh ${ }^{4}$, Klochko $\mathrm{EN}^{5}$, Glukhova $\mathrm{OP}^{6}$ \\ ${ }^{1}$ Southwest State University, Kursk, Russia \\ ${ }^{2}$ Kuban State Technological University, Krasnodar, Russia \\ ${ }^{3}$ Krasnodar branch Plekhanov Russian University of Economics, Krasnodar, Russia \\ ${ }^{4}$ Bauman Moscow State Technical University, 105005, 2-nd Baumanskaya Str., 5, Moscow, Russia \\ ${ }^{5}$ Kuban State Agrarian University named after I.T. Trubilin, Krasnodar, Russia \\ ${ }^{6}$ Naberezhnye Chelny State Pedagogical University
}

Received - September 25, 2020; Revision - November 16, 2020; Accepted - December 14, 2020

Available Online - December 15, 2020

DOI: http://dx.doi.org/10.18006/2020.8(Spl-2-AABAS).S341.S348

\section{KEYWORDS \\ Environmental Impact \\ Economic Impact \\ Factors \\ Environment \\ Water Supply \\ Water Resources \\ Zoning}

Human Activities

\begin{abstract}
Urban development is an objective and irreversible consequence of scientific and technological progress, the result of which is manifested in a change in the urban environment. The advancement of monetary movement over the long run, from the perspective of the economy, is entirely beneficial, yet the development underway volumes are described by a significant level of an anthropogenic effect on the climate. In such a situation, it is quite difficult to prioritize. Analysis of the ecologo-economic state of urban areas, their organization and use, reveals that in the modern conditions of the city's existence, the rational use of urban landscapes is acquiring new dimensions. In this regard, to ensure sustainable development of urban areas, it is necessary to consider and assess both the economy concerning the natural environment and the economy.
\end{abstract}

* Corresponding author

E-mail: lomova-la@yandex.ru (Lomova LA)

Peer review under responsibility of Journal of Experimental Biology and Agricultural Sciences.

Production and Hosting by Horizon Publisher India [HPI] (http://www.horizonpublisherindia.in/).

All rights reserved.
All the articles published by Journal of Experimental Biology and Agricultural Sciences are licensed under a Creative Commons Attribution-NonCommercial 4.0 International License Based on a work at www.jebas.org.

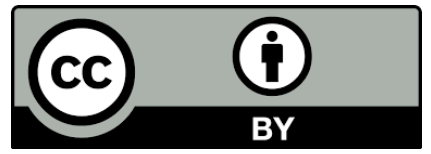




\section{Introduction}

In the current practice of urban areas development, it is customary to consider social, environmental, and economic aspects separately (Ali et al., 2019; Misganaw, 2020). The existing system of rational nature management in modern conditions of deterioration of the quality of the environment is focused on ascertaining the factors of a negative impact and required the implementation of the entire range of research and practical work on these problems.

Therefore, there is a need to ensure the sustainability of the system of rational use of urban areas (Ali et al., 2019). This can best be achieved by conducting a comprehensive environmental and economic assessment of the state of the urban area, and concretizing management decisions in environmental protection. Optimization of this process is possible with the use of modern information support (Bondarenko et al., 2019; Chen et al., 2019; Filatova et al., 2019; Jafarpour et al., 2019).

Based on the above facts, it is advisable to consider the ecologoeconomic aspects of the rational use of urban land in the arrangement and use of territories based on an analysis of the current anthropogenic situation and for the proposal of improving the comprehensive ecological and economic assessment of the state of urban areas to ensure a sustainable system of environmental management.

\section{Materials and Method}

The hypothetical and methodological premise of the examination was the consequences of logical works of homegrown and unfamiliar researchers on the issues of natural financial aspects, uses, security and the executives of land assets in metropolitan conditions, the laws of the Russian Federation, announcements of the Government of the Russian Federation and subjects of the Russian Federation on the issues of utilization and assurance of land assets, distributions on validation and reception of ecologically monetarily stable administration choices, appraisal of the monetary effectiveness of natural insurance measures.

\section{Results and Discussion}

The modern public interest in ecology is understandable. It faced the problem of survival in a highly anthropogenically altered natural environment. The problem of anthropogenic pollution poses a serious threat to the health of the population, causing significant damage to the economy and individual enterprises. There is a real threat of serious damage to the biosphere and the entire geographic envelope as a whole. The first serves as a subject for the study of ecology, and the second - geography. This determines the great similarity and overlap of these sciences (Antipov \& Korytny, 1981; Babkin\&Vuglinsky, 1982; Vasilevskaya, 2012a). In connection with the growth of human economic activity and a significant change in the natural environment, there is an urgent need to assess its state and the degree of favorableness for humans and other living beings.

Environmental assessment is the determination of the degree of suitability (favorableness) of the natural landscape conditions of the territory for human habitation and any kind of economic activity (Vasilevskaya \& Smolyaninov, 2010; Vasilevskaya \& Kosinova, 2014). The ecological landscape assessment includes (i) the establishment of natural landscape differentiation, (ii) determination of the state of landscapes and their components, (iii) establishment of anthropogenic impacts on the landscape, (iv) finding out the potential of landscapes to withstand anthropogenic loads, (v) determination of environmental situations and assessment of the degree of their severity and (vi) development of recommendations for improving the environmental situation.

Leading such an evaluation implies investigating the nature of the climate and its progressions affected by anthropogenic variables. The ecological assessment of the territory is given to identify the main environmental problems inherent in the study area and to determine the severity of the significance of each of them individually and in the aggregate of all. According to Vasilevskaya (2009), Kosinova \& Lomova (2015), and Kosinova \& Lomova (2016), criteria for assessing environmental problems and situations are (i) the degree of pollution of the atmosphere, hydrosphere, soil, erosion, and deflation of soils, degradation of the soil and vegetation cover, depletion of natural resources, (ii) changes in the properties and functioning of the natural system, depletion or loss of natural potential, (iii) urbanization and functioning of industrial enterprises, the degree and nature of emissions, (iv) the number of emissions from vehicles, and (v) socio-medical aspects: living conditions and health of the population.

In geoecology, a person is considered in social, cultural, economic, technogenic environments and geosystems formed by him. This brings geoecology closer to social ecology, which studies the interaction of society and the environment. According to Vasilevskaya \& Kosinova (2015a), a city is an ecosystem that includes 3 interconnected subsystems i.e. (i) Geographic environment - a set of natural, man-made, social and economic living conditions, (ii) Urban population - a set of people connected by social relations and the urban environment that determine the functioning, development, and management of the city, the urban environment: the urban population is the main city-forming factor and (iii) Urban environment - the habitat and production activities of people; a set of natural, man-made, social and economic conditions of human life.

The geoecological state of cities and the quality of the living environment of the urban population are determined, as is known, by a 
combination of natural and anthropogenic factors. The urban environment is not the same for all cities and towns. In recent decades, the quality of the environment has deteriorated not only in large cities, where human economic activity is most intense but also in medium and small ones. Further, researchers of urban areas such as Lomova \& Kosinova (2015) and Vasilevskaya \& Kosinova (2015b) distinguish three groups of processes that affect the successful development of a city, these are (i) Natural: exogenous and endogenous, (ii) Naturaltechnogenic: natural, but quantitatively and qualitatively changed by human activity and (iii) Man-made: arising as a result of engineering and economic human activities.

The development of small towns, regardless of social and, possibly, natural adverse events, will determine their specificity The stable existence of small towns is determined by their direct connection with the natural and natural-anthropogenic environment. The ecological potential of a small city to a much greater extent than a medium and large one depends on the state of its environment, on natural resources, land, forests, historical and architectural landscapes. Material and energy resources of the environment are the main condition for the sustainable existence of a small town. They allow a small city to maintain significant independence from external socio-economic shocks.

Small cities of the forest-steppe zone are more sustainable, which is explained by the high ecological potential of these cities: adaptability to the use of household plots to provide the population with food; the presence of significant reserves of drinking water, energy resources, building materials; use of fertile soils. At the same time, small towns have the main elements of urban infrastructure: communications, hospitals, schools, libraries, warehouses, local industrial enterprises.

The ecological potential of a small town is the property of territory to preserve its structure under the influence of external (natural and man-made) influences, the ability to continue performing socioeconomic functions within specified limits, as well as the ability to perform other and/or additional socio-economic functions of a small town without deteriorating living conditions of the population. Essentially, the ecological potential of a city consists of the aggregate of the potential of the location and the potential of the area. As per Vasilevskaya (2014), location potential can be determined by three groups of factors viz., (i) Transport orientation - striving for minimum transport costs (availability), (ii) Work orientation - the lowest labor costs (labor resources), and (iii) the desire to benefit from the territorial concentration of production.

Location potential is regulated by regional physical-geographical and economic-geographic conditions.

The potential of the area includes natural resources (industrial, construction, recreational, aesthetic) and all those properties of natural conditions that determine the originality of the area, its attractiveness to people, and to create a living environment. If outside the city the microclimate is determined by natural factors, then inside the city the city-planning factors are of decisive importance.

The technological processes of industry and energy, the work of urban transport, emissions into the air basin seriously affect the local climate: the inflow of direct solar radiation to the active surface decreases by $10-25 \%$, but the temperature in the surface layer of the city increases by $7-15^{\circ} \mathrm{C}$.

The microclimate of urban areas, along with general meteorological factors, is mainly determined by the wind regime, the characteristics and nature of the underlying surface. The increased roughness of the surface of urban areas with multi-story buildings significantly affects the nature of air circulation. One of the most significant features of the active surface of the city is the presence in it of semi-enclosed spaces formed by buildings. Due to the mutual irradiation of vertical and horizontal surfaces and weakened ventilation inside semi-enclosed spaces, heat transfer by radiation to the environment is hampered. The presence of various kinds of artificial coatings creates special microclimate conditions (Dolgov, 2002).

Thus, a building density of more than $50 \%$ characterizes predominantly ancient developed territory. Here, the greatest coverage of the surface by various road surfaces is also noted; the areal distribution of technogenic soils, the greatest thermal impact on soils, chemical and biological pollution is possible. In a city with low-rise buildings, natural landscapes prevail natural terrain, open water bodies, parks, forest and other green spaces. The spatial unity of buildings, green areas and water surfaces is ensured, which guarantees the ecological necessities of individuals. Such urban communities are considered as normal and anthropogenic frameworks. For this situation, it is conceivable to protect green spaces equivalent in the territory to the regions involved by blacktop asphalts, structures and different metropolitan structures.

The city is a powerfully working framework (Klindukhova, 2007a; Klindukhova, 2007b). It has such evolved subsystems as a cityframing base, lodging and collective administrations, an arrangement of social administrations, including training, medication and administrations, relaxation and diversion offices, and transport foundation.

The city is an aggregation framework. The equilibrium of hurtful substances inside its cutoff points is generally certain and prompts the collection of past waste and changes. The natural relief of the area is disturbed, there are hills, landslides and sinkholes. Natural surface watercourses are silted up and change direction. They are regularly transformed into the underground, streaming in 
authorities. Common self-purging of water stops and hence the substance of destructive debasements builds, the arrangement of the water changes.

There is a sure example of gathering in the city of marvels, not the trait of living nature. The environment is stopped up with outflows, soils gather destructive substances. The city is an amazingly reliant environment. If all environments are open, at that point urban areas are super-open. They are reliant on their current circumstance. The city devours the regular assets and energy of the city while generating huge amounts of waste.

The city is an unbalanced ecosystem. The ecological balance has been disturbed on its territory. The development and functioning of urban structures are determined, as a rule, not by the laws of nature, but by the needs of people. Such structures are the results of destructive and constructive activities of many generations. Nature reacts ambiguously to transformations. The city devours streams of issue and energy to a lot more prominent degree than it produces. The natural equilibrium is clarified by the fake fascination from an external perspective of an immense measure of streams of substances and energy; hence the environmental equilibrium of biological frameworks is very flimsy.

The city is a combination of fake environmental microsystems: structures constantly of private, mechanical and common stockroom advancement. Structures a lot, being shut, don't speak to self-ruling biological frameworks. They are identified with the climate. Gases, dust and live microorganisms are conveyed into rooms from dirtied outside air. In structures, appropriate air circulation and insolation systems are not generally given, which irritates the environmental circumstance. The ecological solace of the inner climate is fundamentally influenced by commotion contamination of the domains adjoining the turn of events. Disturbers of vibration marvels, for instance, rail transport, act comparably. According to Kravchenko (2006) and Vasilevskaya (2012b), the modern city influences the human environment in three main directions i.e. (i) construction of a qualitatively new environment. The cities themselves have become a kind of habitat; (ii) cities have become hotbeds of active influence on the surrounding area. Each city maintains an active metabolism with its immediate surroundings. The organization of suburban agriculture, the need for water supply and sewage collection are examples of urban metabolism, and (iii) the network of cities began to noticeably influence the course of natural processes. There is an increase in industrial production and traffic flows. The power supply of cities is increasing. The length of the contact zone between the technogenic environment of the city and the rural environment, where natural processes prevail, is increasing.

When analyzing the problems of interaction between man and his natural environment in a modern city, it is fashionable to distinguish three groups of problems as suggested by Lomova et al. (2018), the distinct groups are (i) problems associated with the impact of the anthropogenically modified environment on the urban population, (ii) problems arising from the impact of the polluted urban environment on natural systems, both in the cities themselves and in the adjacent territories and (iii) the problems arising from the impact of the polluted environment of cities on their material and technical facilities.

Let's look at each of these issues. Environmental pollution negatively affects public health. Due to the poor health of workers, productivity and quality of work are reduced. Of particular note is the incidence of children. The impact of urban pollution on natural objects is quite large. Emissions from cities intensively pollute air and water basins and soil. This leads to the destruction of natural systems. Urban planning destroys the lithosphere, changes the regime of soil waters.

Environmental pollution leads to irreversible consequences. Gaseous emissions in cities, containing toxic substances, pollute the territories adjacent to the city, reduce the productivity of crops, and then return to the city along with agricultural products. Contaminated water bodies supply the population with fish containing all those chemicals from industrial plants. And all this in turn affects people's health.

The development of cities is an objective and irreversible consequence of scientific and technological progress, the result of which is manifested in a change in the urban environment. Spatial differentiation of economic activity determines differences in the nature and intensity of anthropogenic impact on urban areas. The urban area can be characterized as a complex urban-ecological system in which the elements of the natural complex and objects created by man are in close interaction.

The advancement of present-day urbanized scenes, is as of now one of the main cycles in the utilization and improvement of domains, and thus, should be founded on the accompanying arrangements (Vasilevskaya, 2010; Lomova, 2015a):

1. The use of territories should occur mainly through the reconstruction of existing engineering and transport infrastructure facilities, restoration and preservation of urban landscapes;

2. Development of territories depends on the consolidation of urban development, the development of underground space, and transport accessibility of territories;

3. Further improvement of each territory should be focused on human needs.

An important reason for the ecologically unstable state of modern urban areas is the lack of timely reliable information on the results of assessing the components of the urban environment. 
Previously, the principle of mass development was a distinctive feature in the formation and development of urban landscapes. Preservation of this principle makes it possible to provide people with housing, but by increasing the technogenic load on these territories, there is a risk of the formation of ecologically unfavorable territorial zones, which accordingly reduces the efficiency of their use. A way out of this situation is not possible without improving environmental and economic relations and a critical rethinking of the unfavorable trends in the use of urban land that has formed to date.

There is a need to study existing methods for assessing the ecological and economic state of urban areas, which is impossible without analyzing the causes of irrational environmental management. Objective prerequisites for the formation of criterion indicators for a comprehensive assessment of the state of urban areas are an integral part of the formation of a sustainable system of environmental management, allowing to ensure an ecologically stable state of these territories.

The planning framework of the city is a system of main streets and squares, green spaces and water areas, zones of concentration of historical and cultural monuments, preserving the genetically inherent features and characteristics of this city. When developing proposals for the project zoning of the city's territory, the principles of the historical, cultural, and environmental priorities of the decisions taken are consistently observed (Lomova, 2015b).

First, it is the selection of environmental historical areas with a special regime of urban planning activities. Secondly, the placement of new housing construction and social infrastructure facilities in ecologically safe areas with a preliminary set of works on engineering and infrastructure preparation of the area. Development of measures to reduce the negative impact of transport and other sources of impact is of small importance. The design zoning of the city territory should include:

1. Continuity in the functional purpose of the existing territorial zones, if this does not contradict the regulatory requirements of environmental safety, effective and rational use of urban areas.

2. Reconstruction and modernization of urban areas, in particular the presence of public, residential, and recreational areas near the water area of the city.

3. Making changes to the existing system of functional zoning of the urban area by increasing multifunctional zones and reducing the share of territories with specialized functional purposes.

4. Possibility of increasing the area of recreational areas and preserving the historical natural frame in the planning structure of the city.
5. Changing the functional purpose of several productions and communal facilities that are part of residential areas, allowing for the provision of commercial, service, and residential functions on these territories.

6. Increase in the city planning project of the share of residential and public and business zones, due to the reduction of the territories occupied by production facilities.

The formation of the planning structure of the city and the design zoning of the territory are depicted on the main drawing of the general plan of the city. According to the Lomova et al. (2019) a prerequisite, which depends on the presence of three components of the planning structure of urban space are (i) natural framework an interconnected system of recreational areas, water bodies, green spaces, parks and squares intended for the recreation of the population, (ii) the historical and cultural framework of the city represents the historical districts of the city, the main historical transport directions, the system of historical dominants - temples and monasteries, historical green spaces, and (iii) urbanized framework of the territory, forming a system of main transport routes, the main urban centers of the city.

When carrying out the project zoning of the city, first of all, the location of residential zones is to determine, then all the other elements of the city planning structure that ensure the functioning of residential areas should determine. The city, as a habitat, is a complex natural and technogenic system and is a cluster of architectural and engineering structures that provide life support for the population. The development of the industry is the main cityforming factor contributing to the growth of cities, consisting of organizations and enterprises of various industries, the existence of a city without which is not possible (Karelov, 2013). But with all the positive factors and the need for the existence of the municipal economy, there is also a negative side of its activities, in particular, all enterprises and organizations bear a load on the state of the environment. Therefore, this factor must be taken into account when organizing and conducting urban planning activities (Kuzmin\&Sharifullina, 2014; Abramovich et al., 2017; Puryaev et al., 2019; Goryushkina et al., 2019; Zhadovskiy et al., 2019; Zaripova et al., 2019; Prischepa et al., 2020; Kuzmin et al., 2020).

The planning structure of the residential area is depending on the size of the settlements and the characteristics of the territories, taking into account the location of the street and road network on the territory of residential buildings, utility networks, and landscaping areas (Aksenova, 2013; Rahman, 2018; Yemelyanov et al., 2019; Elbendary et al., 2019; Dunets et al., 2018; Dunets et al., 2019; Podoprigora et al., 2019; Dunets et al., 2020; Poltarykhin et al., 2020; Turgaeva et al., 2020). 


\section{Conclusion}

The influence of man on nature, occurring in the direction of the transformation of the existing natural ecosystems and the pollution of the main elements of the environment (atmosphere, water resources, soil), which has assumed a global scale in recent decades, has prompted a huge weakening like the regular habitat. The increased impact on the environment manifested as a response in the form of threats to public health, changes in soil cover, depletion of mineral resources, recreational potential, etc., is becoming threatening. Humanity's awareness of the danger of a global ecological crisis gave rise to new ecological thinking, which led to the emergence of the ecological-economic theory of the development of social systems.

When fuel is burned, raw materials are processed, and industrial and agricultural products are used, prompted a huge weakening like the regular habitat, intensively polluting the territory. In small cities, as in large cities, along with an increased level of environmental pollution, various explicit metropolitan factors influence the idea of the metropolitan way of life. These factors include the following: high population density, active traffic load, an increased level of nervous stress affecting the health of urban citizens.

But environmental pollution has a negative impact on the city itself: the destruction of buildings, structures, industrial equipment is accelerating. Unlike large cities, small towns have closer proximity to agricultural areas and a closer connection with them, which makes it easier and cheaper to dispose of food waste. The ecological problems of cities are not limited to environmental pollution. It is formed under the influence of negative feedback from the polluted and altered environment on the city itself and its population. When analyzing the problems of interaction between man and the environment in a modern city, the following problems can be distinguished

1. Problems associated with the impact of the anthropogenically modified environment on the urban population.

2. Problems arising from the impact of the polluted urban environment on natural systems both in the cities themselves and in the adjacent territories.

3. Problems arising from the impact of the polluted environment of cities on their material and technical facilities.

\section{References}

Abramovich BN, Sychev YA, Zimin RY (2017) Hybrid harmonic compensation device adapted for variable speed drive system. Paper presented at the IOP Conference Series: Earth and Environmental Science 87(3) https://doi:10.1088/1755$1315 / 87 / 3 / 032002$
Aksenova EG (2013) Comprehensive ecological and economic assessment of the state of urban areas in order to ensure a sustainable system of environmental management: abstract dis. ... candidate of economic sciences .Rost. State builds. Un-t. Rostovon-Don, Pp. 24.

Antipov AN, Korytny LM (1981) Geographical aspects of hydrological research. Novosibirsk: Science, Pp.176.

Babkin VI, Vuglinsky VS (1982). Water balance of river basins. Hydrometeoizdat: Pp.191.

Bondarenko AV, Islamov SR, Mardashov DV (2019) Features of oil well killing in abnormal carbonate reservoirs operating conditions. 15th Conference and Exhibition Engineering and Mining Geophysics. European Association of Geoscientists and Engineers (ISBN: 978946282282-5): Pp. 629-633.

Chen T, Babanin A, Al-Qāsim MA, Chapron B, Chen J, Md SHSH (2019) Prototype of web-based daily work report management system using smart pens. Journal of Applied Engineering Science 17(3): 280-283.

Dolgov SV (2002) Hydrological consequences of changes in economic activity in the Kursk region. Izv. RAS. Ser: Geogr 5: 7282.

Dunets AN, Muhamedieva AG, Sycheva IN, Perepechkina EG, Vakhrushev IB, Kulchytskiy AV (2018) Spatial development of tourism based on the structure model of the territorial tourist complex. European Research Studies Journal 21(Special Issue 3): 200-210. https://doi:10.35808/ersj/1373

Dunets AN, Vakhrushev IB, Sukhova MG, Sokolov MS, Utkina KM, Shichiyakh RA (2019) Selection of strategic priorities for sustainable development of tourism in a mountain region: Concentration of tourist infrastructure or nature-oriented tourism. Entrepreneurship and Sustainability Issues 7(2): 1217-1229. https://doi:10.9770/jesi.2019.7.2(29)

Dunets AN, Yankovskaya VV, Plisova AB, Mikhailova MV, Vakhrushev IB, Aleshko RA (2020) Health tourism in low mountains: A case study. Entrepreneurship and Sustainability Issues 7(3): 2213-2227. https://doi:10.9770/jesi.2020.7.3(50)

Elbendary A, Aleksandrova T, Nikolaeva N (2019) Influence of operating parameters on the flotation of the khibiny apatitenepheline deposits. Journal of Materials Research and Technology 8(6): 5080-5090. https://doi:10.1016/j.jmrt.2019.08.027

Filatova I, Shabalov M, Nikolaichuk L (2019) Regulation methods in natural monopoly markets case of russian gas network 
companies. International Journal of Engineering Research and Technology 12(5): 624-630.

Goryushkina NE, Gaifutdinova TV, Logvina EV, Redkin AG, Kudryavtsev VV, Shol YN (2019) Basic principles of tourist services market segmentation. International Journal of Economics and Business Administration 7(2): 139-150.

Ali HH, Al-Betawi YN, Al-Qudah HS (2019) Effects of urban form on social sustainability - A case study of Irbid, Jordan. International Journal of Urban Sustainable Development 11(2): 203-222.

Jafarpour H, Moghadasi J, Khormali A, Petrakov DG, Ashena R (2019) Increasing the stimulation efficiency of heterogeneous carbonate reservoirs by developing a multi-bached acid system. Journal of Petroleum Science and Engineering 172: 50-59. https://doi:10.1016/j.petrol.2018.09.034

Karelov SV (2013) Socio-, ecologo-economic assessment of the state of the territory: monograph; under the general editorship of S.V. Karelova, I.S. Belik. Yekaterinburg: UrFU: Pp.257.

Klindukhova LA (2007a) Problems of water supply in the Kursk region. Problems of regional environmental management and methods of teaching natural sciences in high school: materials VI region. scientific-practical conf. students, graduate students and schoolchildren of the southern educational district and the city of Voronezh. October 2007. - Voronezh: Voronezh. stateped. University Press: Pp. 30-33.

Klindukhova LA (2007b) The degree of anthropogenic pressure on water bodies of the Kursk region. Geoecological studies and their reflection in the geographical formation: Sat. Art. according to the materials of International scientific practical Conference, November 26-27, 2007 Kursk: Kursk, state University, Pp. 91- 95.

Kosinova NA, Lomova LA (2015) Cadastral evaluation of urban lands. In the collection: Modern landscape research in the context of optimizing environmental management. Materials of the international scientific-practical conference.Kursk State University, KRO Russian geographic society, Department of Physical Geography and Geoecology, Pp. 118.

Kosinova NA, Lomova LA (2016) Evaluation of the territory of small towns in the system of the land cadactre. News of the SouthWest State University Series: Engineering and Technology 1(18): $42-49$.

Kravchenko NA (2006)Accounting for natural and anthropogenic indicators in the cadastral valuation of land in small towns of the Kursk region: author. Diserdation, geographical Sciences. Moscow: Pp. 22.
Kuzmin PA, Bukharina IL, Kuzmina AM (2020) An investigation of the biochemical composition of norway maple (acerplatanoides 1.) in the conditions of technogenic stress. [Investigação da composiçãobioquímica do bordo da noruega (acerplatanoides 1.) nascondições de estressetecnogênico] PeriodicoTcheQuimica 17(34): 905-914.

Kuzmin PA, Sharifullina AM (2014) Ecological and physiological reaction of fibre flax on vegetation. Life Science Journal, 11(SPEC. ISSUE 8): 377-379.

Lomova LA (2015a) The impact of anthropogenic factors on the environmental status of groundwater in the Kursk region. Economic security: problems, prospects, development trends. Materials of the II International scientific-practical conference: in 2 parts: Pp. 187-193.

Lomova LA (2015b) The importance of information and documentation reports on water resources of the Kursk region. Documentation support of organizational and production activities Collection of materials of the regional scientific-practical conference: Pp. 69-72.

Lomova LA, Kosinova NA (2015) Methods for assessing the condition of water resources. News of the South-West State University Series: Engineering and technology 4(17): 112-118.

Lomova LA, Voronkova OY, Aleshko RA, Goneev IA, Sochnikova IY, Avdeev Y (2019) Ecological and economic consequences of water pollution. International Journal of Engineering and Advanced Technology 9(1): 7056-7062.

Lomova LA, Epifancev KV, Zhminko NS, Romanova TI, Bolshanik PV, Goneev IA (2018)Use of underground water resources in regions with intensive human management activities. International Journal of Mechanical Engineering and Technology 9(12): 595-607.

Misganaw G (2020) Assessment of dairy value chain sustainability, constraints and opportunities in Aksum, Central Tigray, Ethiopia. Online Journal of Animal and Feed Research 10(1): 41-52

Podoprigora DG, Korobov GY, Bondarenko AV (2019) Acid stimulation technology for wells drilled the low-permeable hightemperature terrigenous reservoirs with high carbonate content. International Journal of Civil Engineering and Technology 10(1): 2680-2696.

Poltarykhin A, Dibrova Z, Kovaleva I, Vasyutkina L, Potekhina E, Zinisha O (2020) World experience in the application of antitrust 
regulation and compliance system. Entrepreneurship and Sustainability $\quad$ Issues $\quad$ 2313-2325. https://doi:10.9770/jesi.2020.7.3(57)

Prischepa OM, Nefedov YV, Kochneva OE (2020) Raw material base of hard-to-extract oil reserves of russia. [Matéria-prima base de reservas de óleo de difícilextraçãodaRússia] PeriodicoTcheQuimica 17(34): 915-924.

Puryaev AS, Puryaeva ZA, Kharisova AR, Puryaev AA (2019) Investigation and explanation of mathematical tooling for accounting non-economic characteristics during the investment project effectiveness' assessing process. IOP Conference Series: Materials Science and Engineering 570, 012074 https://doi.org/10.1088/1757-899X/570/1/012074

Rahman PA (2018) Analysis of stationary availability factor of two-level backbone computer networks with arbitrary topology. Journal of Physics: Conference Series 1015(2). https://doi.org/10.1088/1742-6596/1015/2/022016

Turgaeva AA, Kashirskaya LV, Zurnadzhyants YA, Latysheva OA, Pustokhina IV, \&Sevbitov AV (2020) Assessment of the financial security of insurance companies in the organization of internal control. Entrepreneurship and Sustainability Issues 7(3): 2243-2254. https://doi:10.9770/jesi.2020.7.3(52)

Vasilevskaya LA (2010) Optimization of the use of groundwater resources in regions with intensive human activities (for example, the Kursk region). The dissertation for the degree of candidate of geographical sciences. Voronezh State Pedagogical University. Kursk: 208 p.

Vasilevskaya LA (2012a) Assessment of water supply conditions in the Kursk region. News of Southwestern State University. Series: Technics and Technologies 2-2: 208-211.

Vasilevskaya LA (2012b) Zoning according to the conditions of groundwater formation in the Kursk region. News of Southwestern State University. Series: Technics and Technologies 2-2: 251-254.
Vasilevskaya LA (2014) Geography of the Kursk region Kursk: 120 p.

Vasilevskaya LA, Kosinova NA (2014) The specifics of the development of small towns. News of Southwestern State University. Series: Technics and Technologies1: 99-105.

Vasilevskaya LA, Kosinova NA (2015a) Accounting natural and anthropogenic factors when estimating urban lands. News of the South-West State University Series: Engineering and Technology 2(15): 29-36.

Vasilevskaya LA, Kosinova NA (2015b) Geoecological estimation of land in small cities of the Kursk region. In the collection: Scientific works of the Kursk branch of ROIA. Kursk: Pp. 85-92.

Vasilevskaya LA, Smolyaninov VM (2010) Water supply conditions and the possibility of artificial replenishment of groundwater in the Kursk region. Bulletin of Voronezh State University. Series: Geography. Geoecology1: 77-80.

Vasilevskaya LA (2009)Typification of river catchments on the conditions of water supply in the Kursk region. In: Shmykov (Ed.), Ecological-geographical research in river basins: materials of the third international scientific-practical conference.. Voronezh: VSPU: Pp. 114-120.

Yemelyanov VA, Yemelyanova NY, Nedelkin AA, Glebov NB, Tyapkin DA (2019) Information system to determine the transported liquid iron weight. Paper presented at the Proceedings of the 2019 IEEE Conference of Russian Young Researchers in Electrical and Electronic Engineering, ElConRus: Pp. 377-380. https://doi:10.1109/EIConRus.2019.8656693

Zaripova RS, Ahmetova MH, Kuzmin PA (2019) Ecological and biological features of quickbeam (sorbusaucuparia L.) in the context of an urbanized environment. Journal of Advanced Research in Dynamical and Control Systems 11(5 Special Issue): 1731-1734.

Zhadovskiy IT, Berlinskiy IV, Vasiliev VV, Stogov AV (2019) Influence of the content of caluminate on their physicochemical properties. Journal of Physics: Conference Series 1384(1): 012072 